\title{
ESTADO, DIREITO E RELIGIÃO NA EUROPA MEDIEVAL
}

\author{
STATE, LAW AND RELIGION IN MEDIEVAL EUROPE
}

\author{
1 Viviane Lemes da Rosa \\ ${ }^{2}$ William Soares Pugliese
}

\section{RESUMO}

Estuda-se o panorama estatal da Europa ocidental durante os séculos V a XV, sob um viés da história do direito. A Europa contava com um pluralismo jurídico (direito fragmentado) e com a ausência de um Estado forte, o que permitiu que a Igreja exercesse forte influência sobre diversos aspectos da vida em sociedade, dentre eles o direito. Após abordar o papel da Igreja em relação ao Estado e as características do direito canônico durante a Idade Média na Europa ocidental, concluiu-se que foi somente durante a Idade Moderna que houve uma alteração no panorama geral que permeou a Idade Média.

Palavras-chave: Estado, Religião, Europa medieval

\begin{abstract}
We study the state landscape in Western Europe during the V to XV centuries, under a vision of the history of law. Europe had a legal pluralism (fragmented law) and the absence of a strong state, for what the Church exerted a strong influence on many aspects of life in society, including law. After addressing the relation of Church and state and the characteristics of canon law during the Middle Ages in Western Europe, we concluded that it was only during the modern age that there was a change in the overall picture that has permeated the Middle Ages.
\end{abstract}

Keywords: State, Religion, Medieval europe

\footnotetext{
${ }^{1}$ Mestre em Direito pela Universidade Federal do Paraná - UFPR, Curitiba - PR (Brasil).

E-mail: viviane.ldr@hotmail.com

${ }^{2}$ Doutor em Direito pela Universidade Federal do Paraná- UFPR, Curitiba - PR (Brasil). Professor da Universidade Federal do Paraná- UFPR, Curitiba - PR (Brasil). E-mail: wpugliese@ gmail.com
} 


\section{INTRODUÇÃO}

A Idade Média iniciou com a queda do Império Romano, em 476, e findou com a queda de Constantinopla, em 1453, quando surgiu a Idade Moderna. Trata-se de um período marcado pela ausência estatal, pelo direito fragmentado e pela presença da Igreja em todos os aspectos da vida social.

Diante da ausência de um Estado forte, que impusesse o direito por meio de uma legislação fixa e abstrata, dois fenômenos foram particularmente importantes: a) entre outras instituições que tiveram relativa liberdade para florescer, destacou-se a Igreja Romana, que foi responsável por regulamentar todos os aspectos da vida em sociedade, até mesmo o direito; b) a ordem jurídica foi formada pelo direito consuetudinário, o direito romano, o direito canônico e o direito específico dos povos.

A Igreja tornou-se uma instituição extremamente poderosa: adquiriu uma grande quantidade de terras, elaborou o direito canônico e foi responsável pelos julgamentos ocorridos na inquisição. Pode-se dizer que, em boa parte, a civilização medieval foi criada pela Igreja Romana ${ }^{1}$, que regulamentava desde os pequenos fatos do dia-a-dia até os direitos de família e das sucessões, de acordo com os interesses do papa e sob o rótulo da vontade divina.

É nesse contexto que o direito se desenvolve durante a Idade Média: tendo como base as leis divinas e um Estado ausente, que caminhava junto da Igreja. Nesse estudo, pretende-se realizar uma breve descrição de como funcionavam (entrelaçados) o direito, o Estado e a Igreja durante a Idade Média na Europa Ocidental, visando demonstrar as relações havidas entre esses institutos.

\section{ESTADO, DIREITO E RELIGIÃO NA EUROPA MEDIEVAL}

A Idade Média foi inaugurada por um vazio estatal ${ }^{2}$ decorrente da crise da estrutura do Estado Romano ocorrida no século $\mathrm{IV}^{3}$. Houve uma "carência de toda vocação totalizante do poder político, sua incapacidade de se apresentar como fato global e assimilador de todas

\footnotetext{
${ }^{1}$ GROSSI, Paolo. A ordem jurídica medieval. São Paulo: Martins Fontes, 2014, p. 135.

2 Esse vazio estatal foi preenchido apenas parcialmente durante a Idade Média, pois o momento em que houve "vocação por um poder político completo" (século XIV) coincidiu com o declínio da era política medieval (GROSSI, Paolo. A ordem jurídica medieval. São Paulo: Martins Fontes, 2014, p. 53).

3 GROSSI, Paolo. A ordem jurídica medieval. São Paulo: Martins Fontes, 2014, p. 49 e 53.
} 
as manifestações sociais, sua realização nos acontecimentos históricos medievais cobrindo apenas certas áreas das relações intersubjetivas"4.

Essa ausência estatal abriu espaço para que a religião regulamentasse diversos aspectos que caberiam ao Estado, fortalecendo as estruturas religiosas da época - mesmo porque a maior força da época, a única soberana, era Deus. Sobre a influência religiosa, explica Grossi:

\begin{abstract}
No vazio deixado pela ausência do Estado, munida de sua mensagem de salvação, de seu vigor econômico cada vez mais crescente, das suplências sociopolíticas e culturais de que firmemente se investir cada vez mais, a Igreja foi uma presença viva, eficaz e abrangente, graças também a uma organização paroquial bastante articulada e universalmente difundida, que conseguia penetrar até nos mais remotos recessos rurais. A Igreja inseriu-se no costume, absorveu-o, mas também o plasmou.5
\end{abstract}

Não só a religião, como outras estruturas autônomas tiveram liberdade de desenvolvimento durante a Idade Média. Todavia, isso não implicou, por si só, na total independência entre essas esferas, pelo contrário, todo o medievo esteve permeado pela ideia de hierarquia. Nas palavras de Pietro Costa, “a ordem já está dada e a sua intrínseca e harmoniosa justiça coincide com a diferenciação hierárquica dos seus componentes"6.

A ordem jurídica se relacionava com a "pluralidade e variedade das forças que compõem a sociedade civil", era o "terreno de confluência de forças diversas, resposta às exigências objetivas dos homens e das coisas, e não o artifício preestabelecido nem pelo estamento dos proprietários nem pelos detentores do poder"”.

Havia um pluralismo jurídico no medievo, uma "situação em que distintos complexos de normas, com legitimidades e conteúdos distintos, coexistem no mesmo espaço social". Esse pluralismo era formado pelo direito comum (muito afetado pelo direito romano), o direito canônico e os direitos próprios ${ }^{8}$.

Segundo Hespanha, o direito comum "foi basicamente um direito romano-canónico, apesar de nele estarem também inseridos institutos dos direitos tradicionais dos povos

4 GROSSI, Paolo. A ordem jurídica medieval. São Paulo: Martins Fontes, 2014, p. 50.

5 GROSSI, Paolo. A ordem jurídica medieval. São Paulo: Martins Fontes, 2014, p. 135.

6 COSTA, Pietro. Soberania, representação, democracia: ensaios de história do pensamento jurídico. Curitiba: Juruá, 2010 , p. 104.

7 GROSSI, Paolo. A ordem jurídica medieval. São Paulo: Martins Fontes, 2014, p. 63-64.

8 HESPANHA, António Manuel. Cultura jurídica europeia: síntese de um milênio. Florianópolis: Fundação Boiteux, 2005 , p. $160-161$.

Revista Brasileira de História do Direito | e-ISSN: 2525-9636 | Brasília | v. 2 | n. 1 | p. 284 - 300 | Jan/Jun. 2016. 
europeus. No seu seio, o direito canónico desempenhou um papel menos importante do que o direito romano",

Esse direito comum era subsidiário, somente aplicado pelo juiz nos casos em que o direito próprio apresentava lacunas. Por "direito próprio" quer-se dizer a realidade plural formada pelos direitos dos reinos, os estatutos das cidades, os costumes locais e os privilégios territoriais ou corporativos ${ }^{10}$.

Durante o início da Era Medieval, a ausência de um Estado forte implicou na impossibilidade deste de utilizar do direito como a habitual ferramenta de poder. A ordem jurídica foi deixada de lado e regulou-se tendo por base as relações vividas pelos indivíduos em sociedade. Sobre o tema, explica Argemiro Martins:

\begin{abstract}
O poder real, apesar de ocupar um lugar no topo da hierarquia medieval, era incapaz de impor a sua vontade aos nobres, o que gerou o desaparecimento da atividade legislativa imperial e principalmente o desmembramento do poder judicial nas mãos dos senores feudais. Desta forma, o direito fica adstrito às relações feudo-vassálicas, ou seja, as relações dos senhores com os seus servos. O costume passa a ser a fonte por excelência do direito feudal. Inexistiram escritos jurídicos nos séculos X e XI. (...) A justiça é feita, na maior parte das vezes, apelando para a vontade divina; é a época dos ordálios e dos duelos judiciários. 11
\end{abstract}

O direito comum era variável e formado por ordens abertas e flexíveis, sendo que “cada ordem era um tópico cuja eficácia deveria ser provada, cabendo ao juiz fornecer solução arbitrativa para tanto" "12. As populações eram regidas pelas próprias leis, "pelas regras jurídicas de seu povo, raça, tribo ou nação" (princípio da personalidade do direito) ${ }^{13}$.

Diante da ausência de Estado e de um direito regulamentado por ele, a única orientação e fonte de regras era a "natureza das coisas físicas e sociais, na sua estabilidade meta-humana" ${ }^{, 14}$. Assim, a historicidade era uma característica do direito da época, que, por não sofrer influências burocráticas, seguiu o fluxo histórico ${ }^{15}$.

\footnotetext{
9 HESPANHA, António Manuel. Cultura jurídica europeia: síntese de um milênio. Florianópolis: Fundação Boiteux, 2005 , p. 152. 10 HESPANHA, António Manuel. Cultura jurídica europeia: síntese de um milênio. Florianópolis: Fundação Boiteux, 2005 , p. 168. 11 MARTINS, Argemiro Cardoso Moreira. O direito romano e seu ressurgimento no final da Idade Média. In: Fundamentos da história do direito. WOLKMER, Antonio Carlos (organizador). 4. ed. Belo Horizonte: Del Rey, 2007, p. 193.

12 HESPANHA, António Manuel. Os juristas como couteiros: a ordem na Europa ocidental dos inícios da idade moderna. Análise Social, vol. XXXVI (161), 2001, p. 1191.

13 MARTINS, Argemiro Cardoso Moreira. O direito romano e seu ressurgimento no final da Idade Média. In: Fundamentos da história do direito. WOLKMER, Antonio Carlos (organizador). 4. ed. Belo Horizonte: Del

Rey, 2007, p. 192.

14 GROSSI, Paolo. A ordem jurídica medieval. São Paulo: Martins Fontes, 2014, p. 71.

15 GROSSI, Paolo. A ordem jurídica medieval. São Paulo: Martins Fontes, 2014, p. 74.
} 
A ordem jurídica era, portanto, um conglomerado de ordenamentos eventualmente incompatíveis, o que gerava a preocupação em harmonizá-los. O papel de equilibrá-los cabia ao juiz, caso a caso, guiado pelos princípios gerais ${ }^{16}$.

José Reinaldo de Lima Lopes cita como características da Idade Média: a) o pluralismo de jurisdições; b) a rejeição da legislação pelo desuso; c) a ideologia do direito natural como controle substancial de leis abusivas; d) a subordinação do superior aos direitos tradicionais dos inferiores; d) o costume como fonte do direito (podendo a lei corrigir os costumes irracionais ou desarrazoados); e) o impedimento de interesses particulares como justificação de decisões relativas a um grupo ${ }^{17}$.

Durante os séculos V a IX, aplicou-se o princípio da efetividade; havia um naturalismo jurídico, um apego à praxis, a necessidade de o direito se alinhar aos fatos sociais e regê-los. Elementos como terra, sangue e duração definiam a imperfeição do indivíduo em face da comunidade ${ }^{18}$, e os dogmas da Igreja Romana contribuíram para afastar o individualismo e acentuar a importância da coletividade.

Nos séculos X a XII, houve um processo de modernização do panorama agrário, com aumento de produção e consumo, de circulação da moeda e crescimento demográfico. Surgiu a figura do comerciante e aumentou-se o diálogo entre os indivíduos, os debates e a circulação de informação. Nesse contexto, as cidades tornaram-se figuras importantes, pois consistiam nos locais onde os comerciantes se encontravam para trocar produtos ${ }^{19}$. Esse cenário impulsionou uma evolução da ordem jurídica.

A partir do final do século XI, surge uma nova consciência jurídica, preocupada com a identificação da lex, com o papel do príncipe e com a observância do direito - a chamada baixa Idade Média ou Idade Média tardia.

\footnotetext{
${ }^{16}$ HESPANHA, António Manuel. Cultura jurídica europeia: síntese de um milênio. Florianópolis: Fundação Boiteux, 2005, p. 173-174.

17 LOPES, José Reinaldo de Lima. O direito na história: lições introdutórias. 3. ed. São Paulo: Atlas, 2008 , p. 75.

18 GROSSI, Paolo. A ordem jurídica medieval. São Paulo: Martins Fontes, 2014, p. 88 e 93.

19 GROSSI, Paolo. A ordem jurídica medieval. São Paulo: Martins Fontes, 2014, p. 159-161.
} 
A lex consistia no "ordenamento produzido pela razão, voltado ao bem comum, redigido por quem governa uma comunidade"; relacionavam-se a ela o populus (que deveria cumpri-la), o jurista (que lhe dava forma técnica e conteúdo) e o príncipe (que a sancionava $)^{20}$.

Havia uma associação entre soberano e juiz, na medida em que o rei era representado como o juiz supremo, que exercia seu poder declarando um direito já existente, decorrente do mundo dos fatos ${ }^{21}$. O soberano era o único detentor da iurisdictio ${ }^{22}$ plenissima que associava "realeza" e "justiça”, poder e juízo -, pois não submetido a controle ${ }^{23}$.

A lex pertencia à realidade objetiva e era legitimada pela natureza; seu conteúdo (aequitas) já existia e deveria ser apenas revelado pelo legislador. A aequitas consistia na equidade, em um "conjunto ordenado e harmônico de fatos, princípios e regras". Nesse contexto, o papel da ordem jurídica era descobrir o conteúdo da aequitas, redigi-lo em preceitos e impô-lo ao populus ${ }^{24}$.

A ciência adquiriu um importante papel nesse período, devido a alguns fatores: a) por ser um caminho para a verdade; b) pelo século XI ser caracterizado por lutas contra contaminações laicas, choque contra abusos do clero, fracionamento dos costumes, oposição entre a verdade da Igreja e os costumes; c) a necessidade de estabelecimento de uma ordem por meio da organização; d) a importância de diferenciar o que era autêntico daquilo que foi corrompido pela Igreja durante os seus mil anos de história ${ }^{25}$. Esse papel foi desempenhado pelos homens da ciência, os doctores.

Com as modificações sociais ocorridas nos séculos X a XII, o direito costumeiro já não dava conta de tutelar uma sociedade complexa. Como a lei abstrata e rígida não poderia ser instituída naquele momento, diante dos moldes da Idade Média, coube à ciência organizar o novo sistema. De mesmo modo, tendo em vista que o príncipe raramente cumpria a sua função de intérprete, tal papel foi atribuído à ciência jurídica.

20 GROSSI, Paolo. A ordem jurídica medieval. São Paulo: Martins Fontes, 2014, p. 175.

21 COSTA, Pietro. Soberania, representação, democracia: ensaios de história do pensamento jurídico. Curitiba: Juruá, 2010, p. 105-106.

22 A iurisdictio "consistia na faculdade de dizer o direito numa causa em que dois interesses particulares e contrapostos entravam em conflito" (HESPANHA, António Manuel. Cultura jurídica europeia: síntese de um milênio. Florianópolis: Fundação Boiteux, 2005, p. 219).

23 COSTA, Pietro. Soberania, representação, democracia: ensaios d e história do pensamento jurídico. Curitiba: Juruá, 2010, p. 110.

24 GROSSI, Paolo. A ordem jurídica medieval. São Paulo: Martins Fontes, 2014, p. 177.

25 GROSSI, Paolo. A ordem jurídica medieval. São Paulo: Martins Fontes, 2014, p. 180-181. 
Diante da considerável assunção de competências pela ciência jurídica, houve um aumento de sua importância, de seu poder e da preocupação com questões de validade e obediência.

O Plácito de Márturi, ocorrido em 1076 na Toscana, foi o marco de uma redescoberta do direito romano de Justiniano, na medida em que este poderia ser o momento de validade buscado pela ciência ${ }^{26}$. Pode-se afirmar três fases de reinserção do direito romano: a) séculos XVII e XIII: predominância do direito romano na doutrina; b) séculos XIV e XV: desenvolvimento do direito justinianeu; c) a partir do século XVI: supremacia dos preceitos legais sobre direito privado clássico ${ }^{27}$.

A Escola dos Glosadores surgiu na primeira metade do século XII, quando o direito justinianeu passou a ser ensinado em Bolonha, tendo como características mais expressivas "a fidelidade ao texto justinianeu e o caráter analítico e não sistemático" 28 . Essa escola trabalhava por meio da "glosa" - uma breve explicação sobre um trecho obscuro ou difícil do texto do Corpus Iuris - e foi responsável pela criação de uma linguagem técnica sobre o direito ${ }^{29}$. Seus expoentes foram Irnério, Acúrsio, Azo, Hugo, Odofredo, Martinho, Búlgaro, entre outros.

O direito justinianeu tinha traços evidentemente católicos; o Corpus Iuris era fundado na sacralidade e na veneralidade e consistia em uma garantia segura ${ }^{30}$. Sobre o Corpus Iuris e sua relação com o soberano, explica Pietro Costa:

\footnotetext{
O imperador é para o jurista um símbolo de validade, a válvula de fechamento do sistema jurídico. Ele não é tanto a encarnação de uma vontade onipotente quanto é o fundamento de validade de um sistema normativo - o Corpus Iuris - retirado do longínquo passado da Roma imperial e colocado em uma espécie de presente eterno. Se é verdadeiro, assim, que o Corpus Iuris é, quanto à sua origem, o fruto de uma vontade de legislar, é igualmente verdadeiro que para o jurista medieval ele parece principalmente a expressão de uma racionalidade capaz de conter em si mesma a essência da ordem.31
}

\footnotetext{
26 GROSSI, Paolo. A ordem jurídica medieval. São Paulo: Martins Fontes, 2014, p. 193.

27 MARTINS, Argemiro Cardoso Moreira. O direito romano e seu ressurgimento no final da Idade Média. In: Fundamentos da história do direito. WOLKMER, Antonio Carlos (organizador). 4. ed. Belo Horizonte: Del Rey, 2007, p. 194-195.

28 198.

29 HESPANHA, António Manuel. Cultura jurídica europeia: síntese de um milênio. Florianópolis: Fundação Boiteux, 2005, p. 199-200.

30 GROSSI, Paolo. A ordem jurídica medieval. São Paulo: Martins Fontes, 2014, p. 194.

31 COSTA, Pietro. Soberania, representação, democracia: ensaios de história do pensamento jurídico. Curitiba: Juruá, 2010, p. 111.
} 
Assim, o Corpus Iuris se espalhou rapidamente pela Europa ocidental nos séculos XIII e XIV, garantindo à ciência jurídica uma época intensa e fértil, representada por glosadores e comentadores. Como previsto, tornou-se a base formal do discurso e seu momento de validade, e os juristas os seus intérpretes ${ }^{32}$.

As modificações havidas na sociedade dos séculos XIII e XIV (surto urbanista e mercantil) impulsionou uma valorização dos direitos locais, o que gerou a necessidade de introduzir os princípios do direito local no ius commune, visando transformá-lo em um "corpo orgânico dominado por princípios sistematizadores, que correspondesse ao ideal intelectual de um discurso orgânico, embora respeitador de pontos de vista dissonantes" ${ }^{\text {"33 }}$. E o papel de atualizar e sistematizar o direito comum coube aos juristas, mais especificamente aos comentadores:

São estes juristas que, debruçando-se pela primeira vez sobre todo o corpo do direito (direito romano, direito canónico, direito feudal, estatutos das cidades) e orientados por finalidades marcadamente práticas, vão procurar unificá-lo e adaptá-lo às necessidades normativas dos fins da Idade Média.34

Enquanto o príncipe era o representante de Deus na terra, o jurista se limitava a ler o mundo factual e ditar as regras conforme a natureza das coisas (reicentrismo). Aos juristas cabia apenas assumir o direito como algo adquirido; não o criavam, mas interpretavam, observavam, refletiam sobre ele $^{35}$. A função de interpretatio assumiu cada vez maior importância:

\begin{abstract}
Nesse mundo medieval onde Deus é o verdadeiro e único criador do direito, o único verdadeiro legislador graças à Revelação e à natureza, ou seja, graças ao direito divino positivo e natural; nesse mundo onde o direito é sentido como algo ôntico, duradouro, que está além do cotidiano, das suas turbulências e das suas vicissitudes inconstantes; nesse mundo medieval tudo é visto numa abordagem essencialmente interpretativa e é interpretatio a atividade normativa do príncipe e a da comunidade por meio do costume, assim como é interpretatio a justiça feita pelo juiz ou a elaboração teórica feita pelo magister. É uma objeção oportuna, corroborada por tudo o que se disse até agora: interpretatio é a própria ordem jurídica que vive, que se desenvolve lentamente na história.36
\end{abstract}

\footnotetext{
32 GROSSI, Paolo. A ordem jurídica medieval. São Paulo: Martins Fontes, 2014, p. 197-198.

33 HESPANHA, António Manuel. Cultura jurídica europeia: síntese de um milênio. Florianópolis: Fundação Boiteux, 2005, p. 209.

34 HESPANHA, António Manuel. Cultura jurídica europeia: síntese de um milênio. Florianópolis: Fundação Boiteux, 2005, p. 211 .

35 HESPANHA, António Manuel. Os juristas como couteiros: a ordem na Europa ocidental dos inícios da idade moderna. nálise Social, vol. XXXVI (161), 2001, p. 1189.

36 GROSSI, Paolo. A ordem jurídica medieval. São Paulo: Martins Fontes, 2014, p. 201.
} 
Detinham legitimidade para a realização da interpretatio o príncipe, o juiz e o mestre, mas, como visto anteriormente, o príncipe raramente desempenhava suas funções. Sendo assim, os glosadores praticamente afastaram a sua função na ordem jurídica, por meio do procedimento que determinou a sua consulta somente nos casos em que a interpretatio não era suficiente e somente se o príncipe estivesse no local.

A atitude filosófica empreendida pelos comentadores pode ser caracterizada como realista (propõe a investigar a natureza das coisas) e racionalista (a investigação é pautada por processos racionais, como a lógica). Surgem, então, novas figuras dogmáticas: a) teoria da pluralidade de situações reais: o dominium deixa de ser exclusivo; b) aplicação espacial dos ordenamentos jurídicos: as leis deveriam vigorar de acordo com o território e não com a origem da população; c) teoria da naturalidade do poder político (iurisdictio): existência de um poder natural, pertencente à própria ordem das coisas ${ }^{37}$.

O apreço pelos costumes permaneceu na nova ordem jurídica: “os costumes, ou seja, um costume prolongado no tempo e sustentado pelo consentimento dos usuários, têm dignidade e valor de lei; o costume interpreta as leis de maneira notável, mas também possui força para ab-rogá-las"38.

No século XIV, houve uma crise derivada de fatores de ordem social, climática e demográfica: a) a peste negra iniciada em 1347; b) os prejuízos sofridos pela nobreza com a migração das pessoas do campo para a cidade; c) o fim da Reconquista; e d) o desenvolvimento da economia comercial nas cidades ${ }^{39}$.

Tais fatores deram azo a uma maior regulamentação das atividades econômicas pelo direito - de acordo com o interesse de segmentos específicos da sociedade -, notadamente pelos argumentos do "justo preço" e da "utilidade pública" dos povos das cidades no sistema de relações políticas e a criação de estatutos jurídicopolíticos para diversos segmentos da sociedade, como as corporações religiosas e de mestres, as universidades, algumas profissões e outras figuras (como as viúvas e os pobres) ${ }^{41}$.

\footnotetext{
37 HESPANHA, António Manuel. Cultura jurídica europeia: síntese de um milênio. Florianópolis: Fundação Boiteux, 2005, p. 212-217.

38 GROSSI, Paolo. A ordem jurídica medieval. São Paulo: Martins Fontes, 2014, p. 228.

39 HESPANHA, António Manuel. História das instituições: épocas medieval e moderna. Coimbra: Almedina, 2004, p. 187-189.

40 HESPANHA, António Manuel. História das instituições: épocas medieval e moderna. Coimbra: Almedina, 2004, p. 192 e 197.

41 HESPANHA, António Manuel. História das instituições: épocas medieval e moderna. Coimbra: Almedina, 2004, p. 199-200.
} 
Todavia, o ser humano não era visto e regulamentado individualmente, mas somente dentro dos grupos dos quais fazia parte. Com a crise do feudalismo, a fiscalidade real tornouse o meio para obtenção da renda da população pelo Estado; somente assim, a partir do século XVI, surgiu um compromisso com o estabelecimento de um Estado unitário e absoluto ${ }^{42}$. Tal movimento obteve força nas ordens franciscanas e no nominalismo de Guilherme de Ockham, que deu origem ao positivismo jurídico e cuja característica mais marcante foi o individualismo ${ }^{43}$.

Como visto, a Idade Média findou com a queda de Constantinopla, em 1453. Todavia, seu encerramento não coincidiu com o fim desse panorama jurídico representado até o momento; o marco histórico estabelecido para o fim da Idade Média não se relacionou especificamente com as mudanças ocorridas no plano do direito. Pode-se dizer que, no fim da Idade Média, havia um Estado fraco, um direito fragmentado e não exclusivamente estatal, sendo ambos fortemente influenciados pela Igreja Romana.

\section{O DIREITO CANÔNICO}

O direito canônico apresentou uma evolução gradual, de acordo com os poderes adquiridos pela Igreja. Teve suas raízes no século IV, quando o imperador Constantino possibilitou o exercício da jurisdição do papa sobre os fiéis. No século V, a Igreja adquiriu jurisdição privativa sobre os clérigos e, no século $\mathrm{X}$, obteve jurisdição privativa sobre todas as matérias relacionadas aos sacramentos ${ }^{44}$.

No entanto, até o momento, a autoridade religiosa era muito mais moral do que jurídica: somente a revolução institucional operada por Gregório VII - papa entre os anos

1073 e 1085 - operou uma mudança nesse panorama ${ }^{45}$. Com a reforma gregoriana, o direito canônico tornou-se mais burocrático, formal e com propósitos determinados; a reforma foi rápida, total, universal e socioeconômica ${ }^{46}$.

\footnotetext{
${ }^{44}$ HESPANHA, António Manuel. Cultura jurídica europeia: síntese de um milênio. Florianópolis: Fundação Boiteux, 2005, p. 148.

${ }^{45}$ LOPES, José Reinaldo de Lima. O direito na história: lições introdutórias. 3. ed. São Paulo: Atlas, 2008, p. 68-69.

${ }^{46}$ LOPES, José Reinaldo de Lima. O direito na história: lições introdutórias. 3. ed. São Paulo: Atlas, 2008, p. 74.
} 
Dentre as características do direito canônico à época, pode-se citar: a) o repúdio às ideias de igualdade formal e rigorismo formalístico ${ }^{47}$; b) a dicotomia ente ius divinum e ius humanum; c) possibilidade de aplicações diversas para a mesma norma ${ }^{48}$; d) Deus como garantia da ordem; e) importância da equidade (aequitas) $^{49}$; f) auxiliou na criação do ius commune; g) gerou novas penas, como a "perda de função, confinamento em mosteiro, prisão e prática de obras de caridade" ${ }^{50}$;

As diferenças entre ius divinum e ius humanum podem ser explicitadas conforme a tabela abaixo ${ }^{51}$ :

\begin{tabular}{|c|c|}
\hline Ius Divinum & Ius Humanum \\
\hline Necessidade & Utilidade \\
\hline Revelado por Deus & Revelado pela Igreja \\
\hline Requisito para acesso ao reino dos céus & Utilidade e facilidade \\
\hline Composto por poucas regras essenciais & Grande conjunto de regras \\
\hline
\end{tabular}

Grossi afirma que o direito canônico apresentava duas fontes básicas: a Revelação (o que Deus revelou nas Sagradas Escrituras) e a Tradição (o que Deus revelou por intermédio dos Apóstolos e foi conservado pela Igreja) ${ }^{52}$.

A aequitas apresentava a importante função de fonte e princípio do direito. Pode-se dizer que "a equidade é fonte e origem da justiça"; "é aquela harmonia de fatos que exige igual tratamento jurídico para causas iguais"; "nada mais é do que Deus"; "torna-se justiça no momento em que a vontade humana se apropria dela. Se essa vontade se concretiza em preceitos (escritos ou transmitidos oralmente pelo uso), é qualificada como direito"53.

Segundo Grossi, a aequitas estava presente nas coisas e se projetava nos homens; devia ser retirada do mundo fático, interpretada e reduzida a preceitos. Tinha como objetivo garantir a igualdade substancial, de situações de fatos, mas acabou por possibilitar que o próprio intérprete criasse a norma ${ }^{54}$.

\footnotetext{
${ }^{47}$ GROSSI, Paolo. A ordem jurídica medieval. São Paulo: Martins Fontes, 2014, p. 148.

48 "Para manter seu caráter instrumental, a norma deve poder variar conforme as variações sobre as quais se organiza" (GROSSI, Paolo. A ordem jurídica medieval. São Paulo: Martins Fontes, 2014, p. 152).

${ }^{49}$ GROSSI, Paolo. A ordem jurídica medieval. São Paulo: Martins Fontes, 2014, p. 217.

${ }^{50}$ LOPES, José Reinaldo de Lima. O direito na história: lições introdutórias. 3. ed. São Paulo: Atlas, 2008, p. 68 .

${ }^{51}$ Tabela elaborada com base nas informações trazidas por GROSSI, Paolo. A ordem jurídica medieval. São Paulo: Martins Fontes, 2014, p. 151.

52 GROSSI, Paolo. A ordem jurídica medieval. São Paulo: Martins Fontes, 2014, p. 142.

53 FITTING, H. Juristische Schriften de früheren Mitellalters. Halle, Buchhandlung Waisenhaus, 1876, p. 216 apud GROSSI, Paolo. A ordem jurídica medieval. São Paulo: Martins Fontes, 2014, p. 217.

54 GROSSI, Paolo. A ordem jurídica medieval. São Paulo: Martins Fontes, 2014, p. 220-224.
} 
O direito canônico apresentou institutos muito criticados, dentre eles a dissimulatio e a tolerantia, as quais possibilitavam uma espécie de flexibilização das normas de acordo com as circunstâncias do caso - "as fundações pastorais da equidade canônica impõem a desigualdade formal e o escândalo aparente do pecador 'tolerado' e do justo 'punido",55.

Além desses institutos, havia também uma flexibilidade por meio da ideia de "graça", afinal, o direito estava abaixo do reino dos céus. Os únicos capazes de praticar atos de graça (que modificavam a ordem estabelecida) eram os príncipes, na qualidade de representantes de Deus na terra. Ao imitarem a graça de Deus, os príncipes flexibilizam a ordem humana ${ }^{56}$ :

Enquanto senhor da graça, o príncipe:

- Introduz novas normas (potestas legislativa) ou revoga antigas normas (potestas revocatoria);

- Torna pontualmente ineficazes normas existentes (v. g., desobrigando a lei);

- Modifica a natureza das coisas (v. g., emancipando menores, legitimando bastardos, concedendo títulos nobiliárquicos a plebeus);

- Reformula e redefine aquilo que é devido a cada um (v. g., distribuindo recompensas ou mercês). 57

No entanto, a graça não era uma liberdade absoluta, pois estava limitada à necessidade, utilidade pública, salvação ou justiça. Também deveriam ser observados a equidade, a boa-fé, a justa razão e a indenização aos afetados ${ }^{58}$.

O final do século XI inaugurou a nova fase das "coleções canônicas" - coletâneas de textos que sistematizaram as ideias e dogmas religiosos ao longo do tempo. Sobre esse período da história, explica Paolo Grossi:

\footnotetext{
55 GROSSI, Paolo. A ordem jurídica medieval. São Paulo: Martins Fontes, 2014, p. 264.

56 Dentre as possíveis flexibilizações por meio da graça, cite-se legitimar bastardos, emancipar menores, perdoar criminosos. (HESPANHA, António Manuel. Cultura jurídica europeia: síntese de um milênio. Florianópolis: Fundação Boiteux, 2005, p. 208).

57 HESPANHA, António Manuel. Os juristas como couteiros: a ordem na Europa ocidental dos inícios da idade moderna. Análise Social, vol. XXXVI (161), 2001, p. 1192-1193.

58 HESPANHA, António Manuel. Os juristas como couteiros: a ordem na Europa ocidental dos inícios da idade moderna. Análise Social, vol. XXXVI (161), 2001, p. 1193.
} 


\begin{abstract}
E depois, o novo século, com toda a carga de novidade de que é portador: de um lado, uma Igreja que sai vencedora da controvérsia com o Império, mais desejosa ainda de definir-se como ordenamento jurídico, de produzir um direito não mais ofuscado na teologia como aquele que - no início - servira de maneira notável à luta contra os heréticos; de produzir um direito com a mesma qualidade técnica do direito civil e, portanto, dotado de força expansiva em toda a sociedade; de produzir - orientar e condicionar - um valioso instrumento de controle da vida social; de outro lado, um renovado fortalecimento cultural que já é patrimônio difuso; uma reflexão jurídica que não é mais uma manifestação imprecisa de empiristas, mas análise científica, racional, rigorosa, solidamente fundada.59
\end{abstract}

Em 1140, Graciano elaborou o "Concordia Discordantium Canonum", mais conhecido como o "Decreto". Tratava-se de uma coleção canônica de sistematização orgânica, com mais de 3.800 textos, os quais contavam com seus comentários pessoais ${ }^{60}$. A partir do método escolástico, Graciano organizou, hierarquizou e expressou os princípios para eliminação de antinomias, utilizando-se de quatro critérios: a) ratione significationis; b) ratione temporis; c) ratione loci; d) ratione dispensationis ${ }^{61}$.

Tal obra revolucionou a Igreja e fez sucesso na Europa, pois consistiu na primeira obra semelhante ao Corpus iuris, a contemplar todo o direito canônico - além de ter servido como arma para a política teocrática do Pontificado romano ${ }^{62}$. Sobre esse uso dos doctores, explica Rogério Dultra dos Santos:

\begin{abstract}
A Igreja passou a monopolizar a produção intelectual jurídica na idade feudal. Define-se a função dogmática dos doutores universitários, doutores não pelo conhecimento, mas pela autorização divina de revelar, ou melhor, de dizer a verdade da lei, legitimando o discurso oficial do papa e da Igreja, de forma extremamente regrada. Tal legitimação deve, assim, ser percebida como fundamentação teórica para um eficaz e real exercício de dominação e submissão levado a cabo pela Igreja na Idade Média: mais que revelar a verdade, o que o jurista canônico externa é a vontade política do poder eclesiástico em fazer valer os seus comandos.63
\end{abstract}

\footnotetext{
59 GROSSI, Paolo. A ordem jurídica medieval. São Paulo: Martins Fontes, 2014, p. 249.

60 GROSSI, Paolo. A ordem jurídica medieval. São Paulo: Martins Fontes, 2014, p. 250.

61 LOPES, José Reinaldo de Lima. O direito na história: lições introdutórias. 3. ed. São Paulo: Atlas, 2008 , p. 79.

62 GROSSI, Paolo. A ordem jurídica medieval. São Paulo: Martins Fontes, 2014, p. 251-252.

63 SANTOS, Rogério Dultra dos. A institucionalização da dogmática jurídico-canônica medieval. In: Fundamentos da história do direito. WOLKMER, Antonio Carlos (organizador). 4. ed. Belo Horizonte: Del Rey, 2007, p. 234.
} 
Posteriormente, surgiram as decretais, consistentes em decisões do Pontífice que tinham por objeto notadamente a aequitas, que se tornou princípio geral e fonte formal do direito $^{64}$. Segundo Lopes, “eram vereditos ou decisões de casos concretos ou de consultas que se tornavam normas gerais" $" 65$.

Após as Decretais de Gregório IX (que elaborou um compilado de tudo que havia sido produzido em direito canônico desde Graciano), houve uma constante burocratização da Igreja, com divisão de competências e de jurisdição e limitações do objeto do poder.

Nesse contexto, houve uma racionalização do processo civil canônico, que passou a contar com as seguintes novidades: a) introdução da escrita e perda da oralidade e imediatidade da investigação; b) notário como oficial do tribunal; c) divisão clara das fases processuais; d) surgimento do advogado; e) abolição das provas irracionais (em 1215); f) inserção da ideia de que a investigação visa ao convencimento judicial; g) introdução dos princípios de aceitabilidade das provas (probabilidade, relevância e materialidade); $h$ ) poderes investigatórios do juiz; i) sistema da prova legal (juiz é obrigado a valorar a prova de acordo com a lei) ${ }^{66}$.

Quanto à sentença e à coisa julgada no direito canônico, em artigo que tem por objeto a análise dos efeitos da sentença canônica e dos institutos que podem ser compatibilizados com o processo civil atual, Eduardo Talamini explica que foi apenas com a estabilização do direito canônico por meio do Decretum que houve a diferenciação entre sentença e coisa julgada no direito canônico:

\footnotetext{
64 GROSSI, Paolo. A ordem jurídica medieval. São Paulo: Martins Fontes, 2014, p. 261.

65 LOPES, José Reinaldo de Lima. O direito na história: lições introdutórias. 3. ed. São Paulo: Atlas, 2008 , p. 80.

66 LOPES, José Reinaldo de Lima. O direito na história: lições introdutórias. 3. ed. São Paulo: Atlas, 2008 , p.87-90.
} 
Portanto, foi depois da "estabilização" do direito canônico com o Decretum que se veio a esboçar o princípio da permanente possibilidade de determinadas causas serem revistas. Coube aos glosadores do Decretum, às decretais de Papas posteriores e às obras de outros doutrinadores essa tarefa. Foi então que se formulou o conceito de transitus in rem iudicatam, "trânsito em julgado", "passagem em julgado". É que, até esse momento, res iudicata era noção que se identificava com a da própria sentença ou, quando menos, com o efeito essencial de qualquer sentença. No instante em que se começaram a conceber sentenças que não eram imutáveis, já não era mais possível a identificação entre as duas categorias. Daí a distinção entre a sentença, considerada em si mesma, e a "passagem em julgado", consistente na condição de irrevogabilidade, que não precisa estar presente em todas as sentenças. Eis uma das principiais contribuições do processo canônico para o instituto da coisa julgada. Com a distinção, reconhecia-se a existência de um momento formal em que a sentença adquire a força de coisa julgada - momento esse que não se identifica necessariamente com o do surgimento da própria sentença. Mais do que isso, estabelecia-se que nem toda sentença definitiva precisaria revestir-se dessa eficácia. O conceito de "trânsito em coisa julgada" foi rapidamente assimilado pelos juristas do ius civile. 67

Segundo o autor, o direito canônico trouxe várias contribuições ao direito processual civil, dentre eles a querela nullitatis - ação que visa à declaração de nulidade da sentença e cujas hipóteses de cabimento foram consideravelmente ampliadas pelo direito canônico ${ }^{68}$.

Frise-se que a inquisição medieval foi uma exceção a esse cenário positivo do processo canônico. Instituída para combater as heresias ${ }^{69}$ crescentes durante os séculos XII e XIII, a inquisição consistiu em um tribunal de exceção, no qual o inquisidor, munido de um mandado especial de Roma, sobrepujava o poder local do bispo e realizava julgamentos sem observar o contraditório ${ }^{70}$. Dentre outros fatores, a ocorrência da inquisição foi facilitada pela influência da Igreja sobre o Estado:

Em uma época em que o poder da Igreja estava de tal forma imbricado ao poder do Estado, confundindo-se com este em alguns casos, todas as rebeliões e manifestações políticas assumiam caráter religioso e eram combatidas por um sistema de repressão especificamente montado, com o objetivo de justificar a existência da própria instituição eclesiástica. Por outro lado, a Inquisição espanhola foi citada como um exemplo claro na perseguição de adversários políticos ameaçadores do seu poder e de sua riqueza.71

\footnotetext{
67 TALAMINI, Eduardo. Eficácia e autoridade da sentença canônica. Revista de Processo, vol. 107, p. 24-53, Jul/2002, p. 28.

68 TALAMINI, Eduardo. Eficácia e autoridade da sentença canônica. Revista de Processo, vol. 107, p. 24-53, Jul/2002, p. 28.

69 "O termo heresia englobava qualquer atividade ou manifestação contrária ao que havia sido definido pela Igreja em matéria de fé. Dessa forma, na qualificação de hereges, encontravam-se os mouros, os judeus, os cátaros e albigenses no sul da França, bem como os supostos praticantes de bruxaria" (NASPOLINI, Samyra Haydêe. Aspectos históricos, políticos e legais da inquisição. In: Fundamentos da história do direito. WOLKMER, Antonio Carlos (organizador). 4. ed. Belo Horizonte: Del Rey, 2007, p. 235).

70 LOPES, José Reinaldo de Lima. O direito na história: lições introdutórias. 3. ed. São Paulo: Atlas, 2008, p.91-93.

71 NASPOLINI, Samyra Haydêe. Aspectos históricos, políticos e legais da inquisição. In: Fundamentos da história do direito WOLKMER, Antonio Carlos (organizador). 4. ed. Belo Horizonte: Del Rey, 2007, p. 246.
} 
O esforço da Igreja em constituir um ordenamento normativo encerrou-se com as Clementinae $^{72}$, sendo que a fonte do direito canônico até 1917 foi o Corpus Iuris Canonici, um aglomerado de fontes oficiais e extraoficiais ${ }^{73}$.

\section{CONCLUSÕES}

A Idade Média nasceu com a queda do Império Romano, no século IV. À época, havia uma ausência estatal que permitiu a aquisição de grande poder pela Igreja Romana (entre outras instituições) e as suas ingerências no campo jurídico, estatal e da vida social em geral.

Havia um sistema jurídico pluralista e hierarquizado, formado pelo direito comum (basicamente consuetudinário e romano), pelo direito canônico e pelo direito dos povos. $\mathrm{O}$ soberano era Deus, representado na terra pelos príncipes, que eram responsáveis pela interpretação das normas fornecidas pelo mundo fático.

Com as graduais evoluções da vida em sociedade, o direito passou por uma transformação, notadamente no fim do século XI, com a utilização da ciência e dos juristas para a organização e sistematização do conhecimento jurídico. O direito canônico também foi revolucionado com o passar do tempo, caracterizando-se pela burocratização e flexibilização das normas.

O direito passou a contar com alguns "apanhados" de normas - como o Corpus Iuris (de origem romana), o Decreto de Graciano, as Decretais de Gregório IX e o Corpus Iuris Canonici (estes últimos de natureza canônica) - e com a participação ativa dos juristas (glosadores e comentadores) na interpretação do direito. A partir do século XII, a Igreja passou pelo período da inquisição, em que lutava contra a gradual perda de poder através da punição severa de supostas heresias.

A Idade Média teve seu fim sem que tal panorama fosse alterado, deixando como legado para a Idade Moderna a confiança na razão humana proveniente de São Tomás de Aquino e o nominalismo de Guilherme de Ockham, que deram origem, respectivamente, à laicidade e ao individualismo da época moderna ${ }^{74}$.

\footnotetext{
72 GROSSI, Paolo. A ordem jurídica medieval. São Paulo: Martins Fontes, 2014, p. 256.

73 GROSSI, Paolo. A ordem jurídica medieval. São Paulo: Martins Fontes, 2014, p. 257.

74 VILLEY, Michel. A formação do pensamento jurídico moderno. São Paulo: Martins Fontes, p. 180.
} 


\section{REFERÊNCIAS BIBLIOGRÁFICAS}

COSTA, Pietro. Soberania, representação, democracia: ensaios de história do pensamento jurídico. Curitiba: Juruá, 2010.

GROSSI, Paolo. A ordem jurídica medieval. São Paulo: Martins Fontes, 2014.

HESPANHA, António Manuel. Cultura jurídica europeia: síntese de um milênio. Florianópolis: Fundação Boiteux, 2005.

. História das instituições: épocas medieval e moderna. Coimbra: Almedina, 2004.

. Os juristas como couteiros: a ordem na Europa ocidental dos inícios da idade moderna. Análise Social, vol. XXXVI (161), 2001, p. 1183-1208.

LOPES, José Reinaldo de Lima. O direito na história: lições introdutórias. 3. ed. São Paulo: Atlas, 2008.

MARTINS, Argemiro Cardoso Moreira. O direito romano e seu ressurgimento no final da Idade Média. In: Fundamentos da história do direito. WOLKMER, Antonio Carlos (organizador). $4^{\mathrm{a}}$ ed. Belo Horizonte: Del Rey, 2007.

NASPOLINI, Samyra Haydêe. Aspectos históricos, políticos e legais da inquisição. In: Fundamentos da história do direito. WOLKMER, Antonio Carlos (organizador). 4. ed. Belo Horizonte: Del Rey, 2007.

SANTOS, Rogério Dultra dos. A institucionalização da dogmática jurídico-canônica medieval. In: Fundamentos da história do direito. WOLKMER, Antonio Carlos (organizador). 4. ed. Belo Horizonte: Del Rey, 2007.

TALAMINI, Eduardo. Eficácia e autoridade da sentença canônica. Revista de Processo, vol. 107, p. 24-53, Jul/2002.

VILLEY, Michel. A formação do pensamento jurídico moderno. São Paulo: Martins Fontes, 2005. 